\title{
RECENT PROGRESS IN NORTH AMERICAN AVALANGHE FORECASTING AND CONTROL
}

\author{
By E. R. LaChapelle \\ (United States Forest Service)
}

\begin{abstract}
Aвstract. The techniques of avalanche forecasting and control have found increasingly wide adoption in North America in the past decade. Numerous government and private agencies are now engaged in work to protect ski areas, highways, railroads and power lines. Practical control measures such as artillery fire other than snow sheds is still in its of effectiveness, but the construction of permanent defense structures structures and the use of instrumentation, forecasting, defense

artillery and jet aircraft is currently in progress.
\end{abstract}

Amérique du Nord au cours des dix prévision et du contrôle des avalanches se sont largement déveioppées en actuellement de la protection des pistes de ski, annees. De nombreux organismes officicls ct privés s'occupent pratiques de contrôle éction des pistes de ski, grandes routes, voies ferrées et lignes ćlectriques. Des mesures construction d'ouvrages de défense permanents ont été développées jusqu'à une grande efficacité, mais la Les recherches experimentales pour prévision, des ouvrages de protection et le portent sur le perfictionnenent des instruments utilisés, de la

ZuSAmmenfassung. Methoden der Vorhersage und Beherrschung von Lawinen wurden in den letzten Privatindustrie arbeiten a Praktische Schutzmassnahmen, wie etwa Artillerie-Fener, Strassen, Eisenbahnen und Überlandleitungen. während der Bau permanenter Wie etwa Artillerie-Feuer, haben einen hohen Wirkungsgrad erreicht, schuhen steckt. Die derzeitige experimentelle And Schutzbauten (ausser Galerien) noch in den Kinderund die Verwendung von Sprengstoffen, Artillerie und Düsen-Flumenticrung, Vorhersage, Verbauungen,

\section{PART I-Introduction}

Avalanche control work in North America has only recently become a routine activity in certain hazardous mountain areas of the western United States, Canada and Alaska. The history of avalanche dangers is a long one, dating to early penetration of the mountainous West by miners and trappers a century and more ago. The silver mining camps in the western states, particularly Colorado and Utah, were the scenes of many avalanche disasters prior to the turn of the century, but active avalanche control or preventive measures were unknown at that time. Construction of transcontinental railroads across the higher mountain ranges was the occasion of the earliest recorded defense measures (Cunningham, ${ }^{1}$ Muckleston ${ }^{2}$ ), which were then confined to snow sheds and deflection walls. The creation of man-made avalanche dangers through uncontrolled forest fire destruction was an important contribution to hazard in the early railroad passes.

It is surprising that the disastrous avalanche winter of $1909-10$ (Beals ${ }^{3}$ ) did not create wider interest in avalanche defense measures. Public attention was especially directed to the problem by the Wellington tragedy near Stevens Pass, Washington, where IoI persons were killed by an avalanche which swept three trains off their tracks and into a canyon below $\left(\right.$ Hubbard ${ }^{4}$ ). The passage of time quickly relegated avalanche problems to a few isolated mountain communities, and little active concern was found except at certain railroad passes, where snowsheds were the only common countermeasures. Eventually, two major transcontinental railroads, at Rogers Pass, British Columbia and Stevens Pass, resorted to tunnels to avoid the most serious dangers.

The modern development of avalanche control in the United States originated with the advent of skiing as a popular winter sport. Beginning in the winter of 1937-38, the U.S. Forest Service 5 assigned men to full-time duty on snow safety problems in ski areas on National Forest lands. Such work was mostly administrative until I946, when a study program for the development of instruments and techniques for avalanche forecasting and control was established at Alta, Utah. This period coincided with the post-war dissemination 
of information concerning the more fully developed European avalanche techniques, particularly those from Switzerland. Surveys of snow and avalanche problems in the U.S. and Canada were made at this time by de Quervain ${ }^{6}$ in $1948-49$ and by Roch 7 in 1949 . The latter assisted in organizing the avalanche program of the Forest Service. More recently, Fuchs, ${ }^{8}$ working with the U.S. Army Corps of Engineers, has assessed the state of avalanche control work in the United States.

In the past decade progress has been rapid, reflecting an increasing interest by State and Federal agencies as well as by private corporations in active methods of preventing or controlling avalanches. The success of these techniques in the ski areas served to illuminate the practicality of avalanche control on highways and railroads where snow dangers had for years been regarded as an inescapable force of nature. In $195^{\circ}$ the U.S. Forest Service was the only organization in North America engaged in full-time work on avalanche problems each winter. The National Ski Patrol System, a volunteer organization, cooperated on a part-time basis in certain localities. Today the number of organizations so concerned is large and growing each year. This present activity is summarized below in Part II, wherein are listed the agencies and locations known to be engaged in or planning avalanche forecasting and/or control.

\section{Part II-Organizations Fingaged in Avalanche Work}

(1) The United States Forest Service directs widespread work to protect ski areas from danger. Active avalanche control, utilizing a full range of measures from protective skiing to artillery fire, is a regular winter program at several major ski areas. Of these, Alta, Stevens Pass, Berthoud Pass, Colorado and Squaw Valley, California, are also participating stations in research studies on avalanche forecasting and control. At these locations detailed observations of weather, snow cover evolution and avalanche occurrence are maintained throughout the winter. Alta is the central data collection station, where an office and library serve as headquarters for the study program.

An intensive training program has been in operation since 1949 , designed primarily for Service personnel, but it is also utilized widely by the National Ski Patrol System and other Government and private agencies.

(2) The ski patrols are in many areas active participants in avalanche work. The National Ski Patrol System requires rescue training of all its fully qualified patrolmen, which has served to form a nucleus of competent avalanche rescue personnel in the United States. In some localities NSPS men conduct such active control work as artificial release by blasting.

Professional patrols at certain major ski resorts where avalanche hazard exists, st:ch as Aspen, Colorado and Sun Valley, Idaho, undertake routine avalanche control. Training of both these and the volunteer patrols is coordinated closely with the Forest Service.

(3) The Colorado Ifighway Department has used artillery fire to reduce highway avalanche dangers for the past decade. A $75 \mathrm{~mm}$. mountain howitzer is stationed in the LovelandBerthoud Passes area (Front Range), and a second similar weapon is used in the SilvertonDurango-Ouray region of the San Juan Mountains. Artificial avalanche release to reduce hazard is a routine task, but blind firing as a preventive measure has not yet been undertaken.

Experimental installations of avalanche defense structures have been made by this Department near Loveland Pass. Wind baffles (Kolktafeln) and snow fences for deposition control have been in place for several years. More recently a diversion barrier has been installed on the outrun of the Bethel Mountain Slide. A snow and weather observation station to aid in hazard forecasting has been operated intermittently near Loveland Pass.

(4) The Washington State Highway Department has experimented with artificial avalanche release by blasting at Stevens Pass, but this has not yet become fully established as a routine measure. Two large snowsheds have been constructed near Snoqualmie Pass to provide avalanche protection for a major four-lane highway. 
(5) The United States Bureau of Public Roads organized a program of avalanche investigation and control in 1957 for certain dangerous areas in Alaska. The principal site for this work has been Girdwood, Alaska, where both an important highway and a railroad are threatened by a series of avalanche tracks. An observation station with a full schedule of snow, weather and avalanche records is in operation at Girdwood. A number of successful installations of avalanche breaker mounds have been made here and at other sites near Anchorage, Alaska. Some use has been made of artillery fire in cooperation with the U.S. Army. Weather and avalanche occurrence records have been initiated in areas where future highway construction is proposed.

(6) The Government of Canada has begun the first large-scale study of avalanches in that country while planning for construction of the new Trans-Canada Highway through the Selkirk Mountains of British Columbia. Collection of snow, weather and avalanche records began at Rogers Pass in 1955, and has continued to date. Tests have been made of defense installations and artillery fire in preparation for the opening of the new highway scheduled by ig6r. The most dangerous sections of this highway will be protected by snowsheds. Rogers Pass probably is the most difficult highway avalanche problem in North America at the present time, and a full range of protective measures from defense structures to routine artillery fire is planned.

(7) On 26 January 1955 an avalanche near Kildala Pass, British Columbia, destroyed three towers of the Kitimat-Kemano power transmission line serving the Aluminum Company of Canada's major aluminum smelter at Kitimat, B.C., and interrupted service for nine days. The protective measures designed for this power line to prevent repetition of such a costly interruption probably represent one of the largest expenditures to date on completed avalanche defenses in North America. Largely utilizing helicopters, a cross-valley suspension system was installed, supporting the transmission line completely free of the avalanche paths (White ${ }^{9}$ ). Towers on other sections of this line also receive protection from diversion barriers and V-shaped deflectors constructed of heavy rubble. Experience over several winters has proven these barriers to be very effective.

(8) The United States Army Corps of Engineers has sponsored a continuing scries of investigations on snow stratigraphy in relation to avalanche formation at Berthoud Pass, Colorado (Borland ${ }^{10}$ ). In the winter of $1955-56$ this agency engaged in a cooperative investigation of explosives in snow with the United States Forest Service.

(9) The National Park Service is confronted with avalanche hazard during the annual spring snow-clearing operations to re-open a highway over Logan Pass in Glacier National Park, Montana. Experiments are currently under way to reduce or control the occurrence of wet spring slides which endanger the highway crews. A test of artillery fire is scheduled for May 1960 and a new technique has been tested to encourage winter avalanching to relieve the snow burden on the mountain sides. (See Part III below.)

(Io) The California Highway Department is planning the use of artillery to reduce avalanche hazard on U.S. Highway 50 across the Sierra Nevada Range. Such work is presently done by cooperative agreement with the U.S. Forest Service on Highway 40 in this same region.

( I I) The Nevada Highway Department is planning an avalanche control program for an endangered section of highway on Mt. Rose, Nevada.

(12) A sustem of avalanche fences to protect the Southern Pacific Railroad main line near Donner Summit, California, is in the design stage.

\section{Part III-Progress in Techniques}

(1) Artillevv Fire

Following the methods established in Switzerland, artillery fire has been introduced in North America, where in the past several years it has found wide adoption as an effective 
means of avalanche prevention and control. A number of weapons have been tested for this purpose, mainly at the instigation of the U.S. Forest Service. The most satisfactory weapons have proven to be the $75 \mathrm{~mm}$. mountain howitzer and the $75 \mathrm{~mm}$. and $105 \mathrm{~mm}$. recoilless rifles. These combine the desirable features of accuracy, safety, reasonable ease of transport and simplicity of operation. Mortars, bazookas, rifle grenades and heavy field artillery were also tested but were found less satisfactory. Experience in the United States thus differs somewhat from that in Switzerland, where mortars have long been the standard weapon for avalanche control. The trend in the United States has been strongly in favor of flat-trajectory weapons which insure accurate fire and, most important, positive surface detonation of the high-explosive shell. Both are considered important safety features. Mortars have given an undesirably high number of duds and undetectable sub-surface explosions in soft snow, sources of danger almost unknown with the recoilless rifles.

Portable weapons are used in a number of areas for highway protection, as mentioned above in Part II. Recently permanent, fixed, installations of recoilless rifles have been made at Squaw Valley, California and at Alta. The gun tower for a $105 \mathrm{~mm}$. rifle at Alta is illustrated in Figure r, p. 685. Such fixed gun mounts permit establishment of accurate blind firing data and consequent improvement in control and preventive measures.

Alta and, more recently, Squaw Valley, are the only locations where blind firing has become an established routine. By thus preventing avalanche build-up during storms, and by routine firing at avalanche slopes after every major snowfall whether a serious hazard exists or not, a very marked gain in safety through avalanche prevention has been achieved. Slopes at Alta which formerly yielded frequent large avalanches are now only rarely active as a result of routine and regular artillery fire.

(2) Defense Structures

Avalanche control measures in North America to date have been predominantly of the type designed to alter temporarily the character of an existing snow cover, such as artillery fire or blasting by hand-placed charges. Defense structures which permanently modify the terrain have only very recently been introduced.

Systems of earthen mounds designed to arrest the fall of avalanches have been successfully used in Alaska, following the style of construction developed in Austria. Of particular interest is one such installation near Girdwood, Alaska, which is on a slope steeper than usually considered suitable for mounds. This has proved quite effective in arresting wet slides common to this area. An experimental installation of mounds has also been made near Rogers Pass, British Columbia (Schaerer "1), and Red Mountain Pass, Colorado. See Figure 2.

A large diversion barrier near Loveland Pass, Colorado has recently accomplished its designed purpose by deflecting a large avalanche away from an important transcontinental highway.

A series of experiments has been conducted at Berthoud Pass and Loveland Pass by the Colorado Highway Department and the U.S. Forest Service to test the effectiveness of wind baffles (Kolktafeln). To date these have proven to have only limited value in this area, where wind action is especially intense. Fences for drift control have also been installed in connection with the experiments.

Reforestation measures, either separately or in association with defense structures, have not yet been introduced, though there exists wide scope for such measures.

(3) Avalanche Signal Installation

A radio signal system has been installed on several major avalanche paths near Alta, which transmits notice of avalanche occurrence to a central receiving station. The small, battery-operated field transmitters (Fig. 3) are designed to emit a I-watt signal on the rometer band for two minutes following disturbance of a trip wire within the avalanche path. At one location it has been possible to arrange the trip wire automatically to reset itself after smaller slides, so that signals of repeated action during a single storm may be obtained. A 
recent modification of the field transmitters has permitted their burial underground, leaving only the antenna exposed to possible avalanche damage above the snow surface.

(4) Weather Telemetering

The collection of weather data from the altitudes of avalanche release zones is recognized as important to hazard forecasting. At Berthoud Pass, Colorado; Stevens Pass, Washington; and Girdwood, Alaska, information on wind velocities near the higher ridges is transmitted by wire lines to conveniently located recorders. A more sophisticated system, utilizing shortwave radio to transmit both wind and temperature data, has been installed at Rogers Pass as part of the avalanche forecasting program planned for that area.

(5) Hazard Forecasting

Avalanche hazard forecasting is a routine activity at major ski areas under Forest Service administration. The Colorado Highway Department and the Bureau of Public Roads in Alaska base their highway safety work on forecasting procedures. Such work aiso will be an important part of the safety program at Rogers Pass when the Trans-Canada Highway is open to the public.

Forecasting techniques in use by U.S. agencies are based primarily on the empirical methods outlined by Atwater (see U.S. Forest Service ${ }^{5}$ ), strongly reinforced by personal experience of the various forecasters in different areas. The analysis of contributory factors has proved a sound means of evaluating slide hazard, particularly for slab avalanches which fall during or immediately after heavy snowfalls. Such evaluations constitute a forecast when they are projected into the future on the basis of mountain weather forecasts. Difficulty in obtaining accurate mountain weather predictions over the widely scattered ranges of the West has been one of the principal obstacles to accurate hazard forecasting.

(6) Research

Avalanche studies in the United States have to date been directed toward practical applications in forecasting and control. Very little work so far has been done on basic snow mechanics and theoretical investigations. The U.S. Forest Service has maintained a continuing study program over the past fourteen years. The principal objectives have been the collection of snow, weather and avalanche data for improvement in empirical forecasting techniques, the development and test of instrumentation to aid in this collection, and the improvement in methods of avalanche release and prevention. A serious limitation on these studies has been the available time and manpower, for most of the work to date has been carried out as a secondary effort along with practical control and safety efforts in certain ski areas. The most fruitful results from this Forest Service work have been the development of forecasting methods based on comparison of a large number of storm records with avalanche occurrence (see, for instance, Atwater ${ }^{12}$ ), improvements in certain instrumentation for collection of wind and precipitation data during winter storms (Atwater and others ${ }^{13}$ ), and improvements in the selection and use of high explosives for avalanche release, as well as establishment of the most efficient methods for artillery fire.

The basis for advances in the use of explosives in snow was laid by a cooperative investigation initiated jointly by the Forest Service and the Snow, Ice and Permafrost Research Establishment. Results of these studies, dealing mainly with the fracturing and disruptive effects of different blasting agents, have been reported by LaChapelle ${ }^{14}$ and Fuchs. ${ }^{15}$

An interesting practical test in avalanche release was begun in the winter of $1959-60$ by the National Park Service in Montana in connection with the highway problem described in Part II. An effort is being made to reduce the spring slide activity by encouraging winter avalanching to relieve some of the snow burden on the slopes. Trigger mechanism used is the sonic boom from low-flying jet aircraft. Through cooperation with the U.S. Air Force, lowlevel winter flights over this area have been made by F-1 66 Delta Dart aircraft at speeds up to Mach 1.2. These aircraft have made aimed supersonic dives at selected target areas in order to concentrate the effects of the shock wave. Ground observers have witnessed a number 
of slab avalanche releases on these occasions which indicate that the sonic boom is a powerful triggering force (Edgar ${ }^{\mathrm{I}}$ ).

The U.S. Army Corps of Engineers has supported investigations of snow stratigraphy in relation to slab avalanche formation, mentioned above in Part II. These have yielded a large body of information of ram profiles typical for slab avalanches as well as a detailed record of weather conditions contributing to the stratigraphic evolution (Borland, op. cit.).

\section{Publications}

The U.S. Forest Service has made publications on avalanche work generally available to the public, the most useful of which has been the Avalanche handbook cited above. A revised and enlarged edition of this reference manual is scheduled for publication late in 1960. Plans are also under way to make certain translations and reports more widely avi.able in English.

The Snow, Ice, and Permafrost Research Establishment has translated a number of important technical works on snow, avalanches and avalanche defense construction which are available in limited circulation to Government agencies. The National Research Council of Canada has also made available some reports and translations in this field.

MS. received 31 March 1960

\section{REFERENGES}

i. Cunningham, G. C. Snow slides in the Selkirk Mountains. Transactions of the Canadian Society of Civil Engineers, Vol. 1, Pt. 2, 1887, p. 18-31.

2. Muckleston, H. B. A short description of the Canadian Pacific Railway through the Selkirks. (In Wheeler, A. O. The Selkirk Range. Vol. 1. Ottawa, Canadian Government Printing Office, 1905.)

3. Beals, E. A. Avalanches in the Cascades and northern Rocky Mountains during winter of I9o9-I9Io. U.S. Weather Bureau. District No. I2. Climatological Summary, June 1910, p. 4-10.

4. Hubbard. F. Avalanche. Argosy. March 1959, p. 60-6i, 96-100.

5. L.S. Forest Service. Avalanche handbook. Washington, D.C., U.S. Government Printing Office, 1952.

6. Ouervain. M. R. de. Snow and ice problems in Canada and the U.S.A. Canada. National Research Council. Division of Building Research. Technical Report No. 5, $195^{\circ}$.

- Roch A. Report on snow and avalanche conditions in the U.S.A. Western ski resorts from the 26 th of January to the 24, th of April 1949. Swiss Federal Institute for Snow and Avalanche Research. Report No. $174,1949$.

8. Fuchs, A. Avalanche conditions and avalanche research in the United States. U.S. Snow, Ice and Permafrost Research Establishment. Report 29, 1955.

9. White, H. B. Cross suspension system Kemano-Kitimat transmission line. Engineering Fournal, Vol. 39 , No. 7,1956 , p. $901-11,926$.

10. Borland, W. M. Investigation of snow conditions causing avalanches. U.S. Army. Corps of Engineers. Interim Reports $\mathrm{I}-7,1953-59$.

I. Schaerer, P. The planning of the avalanche defense for the Trans-Canada Highway at Rogers Pass. Proceedings. Western Snow Conference, ... . Santa Fe, N. M., April 1060. [In press.]

12. Atwater, M. M. The relationship of precipitation intensity to avalanche occurrence. Proceedings. Western Snow Conference, 20 th annual meeting, 21 and 22 April $1952, \ldots$, p. $11-19$.

13. Atwater. M. M., and others. Avalanche research: a progress report. Parts I-2. By M. M. Atwater, E. [R.] LaChapclle, R. M. Stillman and F. M. Foto. Appalachia, N.S., Vol. 20, No. 12, 1954, p. 209-20; N.S., Vol. 21 , No. 7 , 1955, p. 368-80.

14. LaChapelle, E. [R.] Some effects of high explosives on snow: a report on preliminary investigations. U.S. Forest Service. Internal Report, May 1956.

15. Fuchs, A. Effects of explosives on snow. U.S. Snow, Ice and Permafrost Research Establishment. Special Report 23 , 1957 .

16. Edgar, M. Personal communication, r96o. 


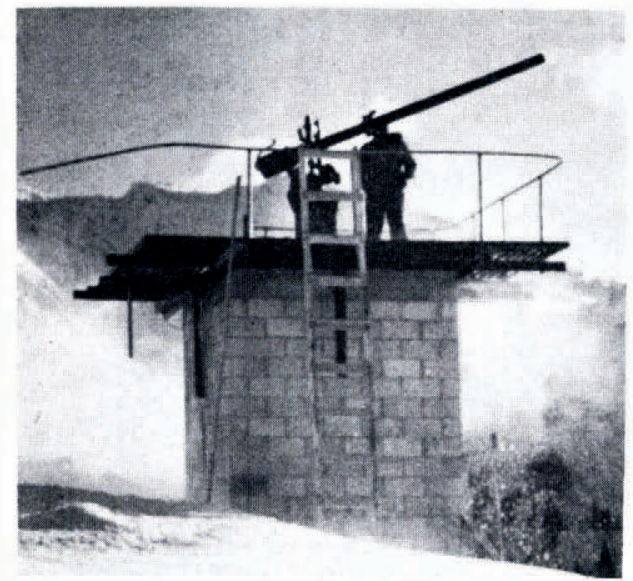

Fig. I
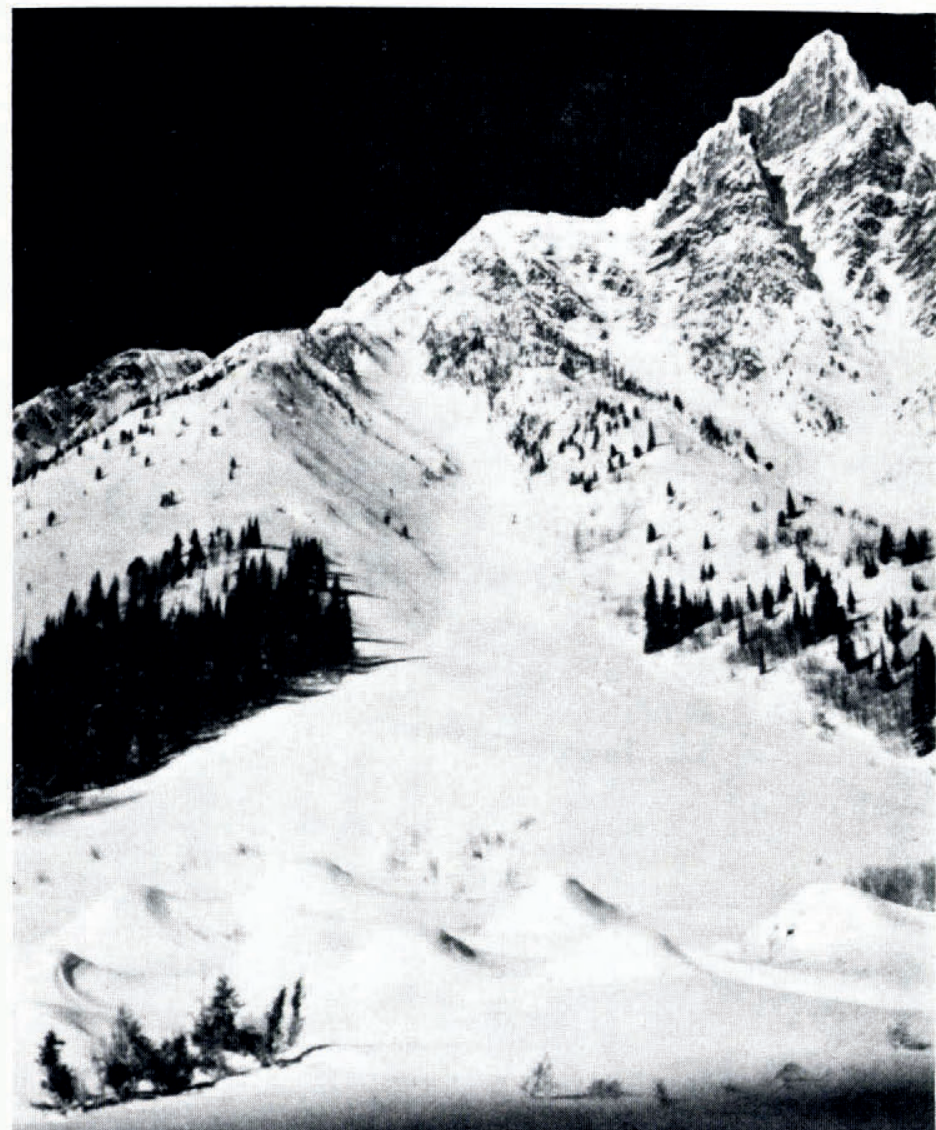

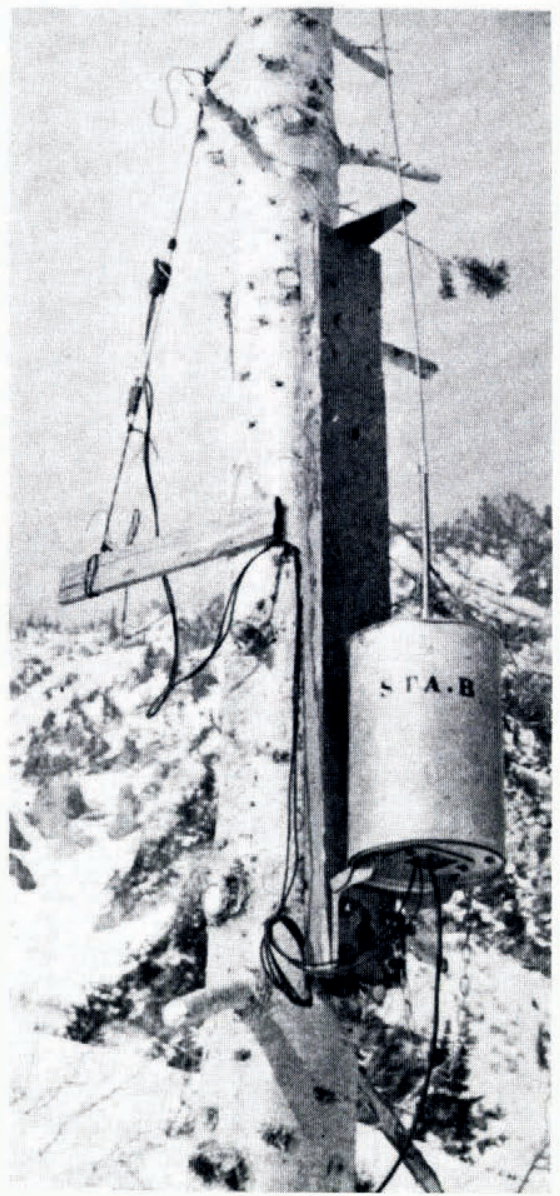

Fig. 3

Fig. I. A $105 \mathrm{~mm}$. recoilless rifle fired for avalanche control. This fixed installation is at Alta, Utah

Fig. 2. Experimental installation of avalanche breaker mounds near Rogers Pass, British Columbia

Fig. 3. Avalanche signal transmitter at Alta. A mercury switch is taped to the shock cord on the left, which in turn is connected by trip wire to the avalanche path 